\title{
Vitamin D - roles in women's reproductive health?
}

\author{
Magdalena Grundmann and Frauke von Versen-Höynck
}

\begin{abstract}
In the past few years a growing interest in vitamin D can be observed in the lay and biomedical literature due to findings demonstrating a low vitamin D status in the population. In addition to its importance for the regulation of calcium and phosphorus homeostasis recent epidemiologic studies have observed relationships between low vitamin D levels and multiple disease states. This secosteroid hormone also regulates the expression of a large number of genes in reproductive tissues implicating a role for vitamin $D$ in female reproduction. In this report we summarize the recent evidence that vitamin D status influences female reproductive and pregnancy outcomes. Human and animal data suggest that low vitamin D status is associated with impaired fertility, endometriosis and polycystic ovary syndrome. Evidence from observational studies shows higher rates of preeclampsia, preterm birth, bacterial vaginosis and gestational diabetes in women with low vitamin D levels. However, confirmation of experimental observations establishing an association of vitamin D deficiency with adverse reproductive outcomes by high quality observational and large-scale randomized clinical trials is still lacking. The determination of optimal 25(OH)D3 levels in the reproductive period and the amount of vitamin D supplementation required to achieve those levels for the numerous actions of vitamin D throughout a woman's life would have important public health implications.
\end{abstract}

Keywords: vitamin D, women?'?s health, reproduction, fertility, pregnancy

\section{Background}

In North America and Western Europe only small amounts of vitamin $\mathrm{D}$, a fat-soluble secosteroid hormone, enter the metabolic circle via dietary uptake (e.g. from fish), although dietary supplement intake has increased in recent years (Figure 1). The main source (about 95\%) is vitamin $\mathrm{D}_{3}$ (cholecalciferol) that is photochemically synthesized in the skin by ultraviolet- $B$ radiation. Thermal conversion of pro-vitamin $\mathrm{D}_{3}$ (7dehydrocholesterol) leads to pre-vitamin $\mathrm{D}_{3}$, which isomerizes into cholecalciferol. Cholecalciferol is bound to serum vitamin D-binding protein (DBP) and through a two-step enzymatic pathway involving 25-hydroxylase of the liver and 1 $\alpha$-hydroxylase (CYP27B1) of the kidney and extrarenal tissues, it is converted to the biologically active hormone calcitriol $\left(1 \alpha, 25(\mathrm{OH})_{2} \mathrm{D}_{3}\right)$ [1]. In a wide variety of cell types vitamin $\mathrm{D}$ exerts its effects by binding to the vitamin $\mathrm{D}$ receptor (VDR), a member of the

\footnotetext{
* Correspondence: vonversen-hoeynck.frauke@mh-hannover.de Department of Obstetrics, Gynecology and Reproductive Medicine, Hannover Medical School, Carl-Neuberg-Strasse 1, 30625 Hannover, Germany
}

nuclear steroid receptor superfamily and an intracellular transcription factor [2]. The regulation of VDR expression is one of the main mechanisms through which target cells respond to calcitriol so that polymorphisms of this receptor can change the usual mode of functioning.

Although $1,25(\mathrm{OH})_{2} \mathrm{D}_{3}$ is the biologically active form of vitamin $\mathrm{D}$ the vitamin $\mathrm{D}$ status is mainly assessed by the measurement of serum $25(\mathrm{OH}) \mathrm{D}_{3}$ concentration. The test is used due to associations between vitamin $\mathrm{D}$, calcium and plasma parathyroid hormone (PTH) $[3,4]$. While becoming vitamin $\mathrm{D}$ deficient the parathyroid glands increase the secretion of PTH to accelerate renal calcium reabsorption and calcium release from bone. Another effect of PTH is the stimulation of renal 1,25 $(\mathrm{OH})_{2} \mathrm{D}_{3}$ production with possibly misleading $1,25(\mathrm{OH})$ ${ }_{2} \mathrm{D}_{3}$ concentrations within the normal range.

Based on associations between plasma $25(\mathrm{OH}) \mathrm{D}_{3}$ and PTH concentration, calcium absorption, bone turnover markers, and bone mineral density, investigators have argued that a plasma $25(\mathrm{OH}) \mathrm{D}_{3}$ concentration of greater than $75 \mathrm{nmol} / \mathrm{l}$ (to convert to $\mathrm{ng} / \mathrm{ml}$ divide by 2.5 ) is 


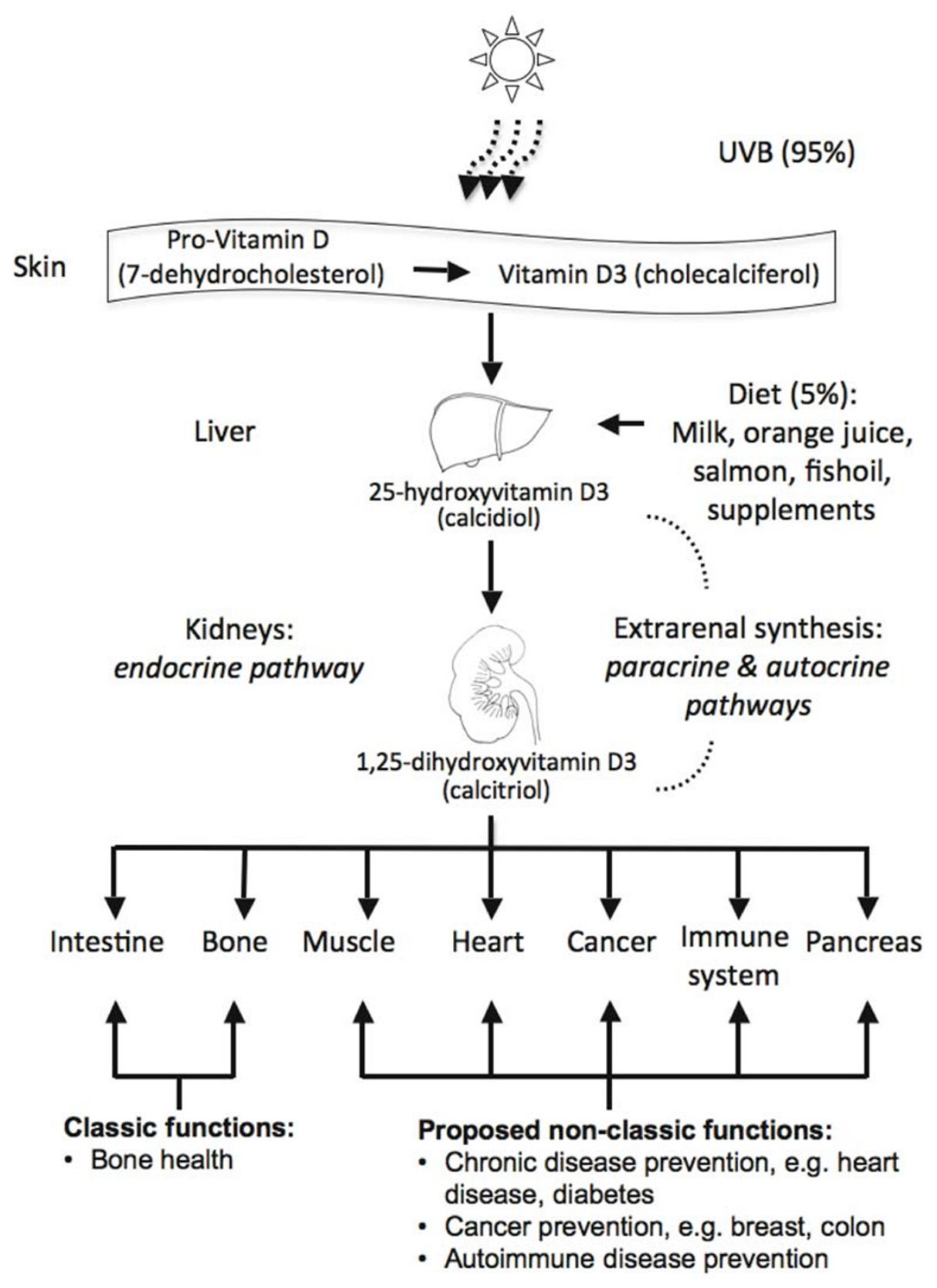

Figure 1 Types and functions of vitamin D

appropriate to define vitamin D sufficiency [5-7]. Precisely defining vitamin $\mathrm{D}$ deficiency or insufficiency is still a matter of great debate. A rather simplistic scheme for the classification of vitamin D status is shown in Figure 2. Although there is currently no consensus for optimal levels, most experts use a plasma concentration of 25 $(\mathrm{OH}) \mathrm{D}_{3}$ of $25 \mathrm{nmol} / \mathrm{l}$ as a conventional cut-off for defining the lower limit of adequacy of vitamin D status [8]. These cutoffs were derived from populations of nonpregnant individuals. However, recent evidence demonstrates that the prevalence of vitamin D deficiency in women of childbearing age is surprisingly high [9-12].

Vitamin D plays a pivotal role in bone metabolism and mineral homeostasis. Emerging data identify critical roles for the active form of vitamin $\mathrm{D}\left(1 \alpha, 25(\mathrm{OH})_{2} \mathrm{D}_{3}\right)$ in a variety of other biological processes including regulation of cellular growth, differentiation and metabolic modulations $[13,14]$. Beneficial roles for vitamin D in a spectrum of pathologic processes, including autoimmunity, insulin resistance, cardiovascular disease, and 


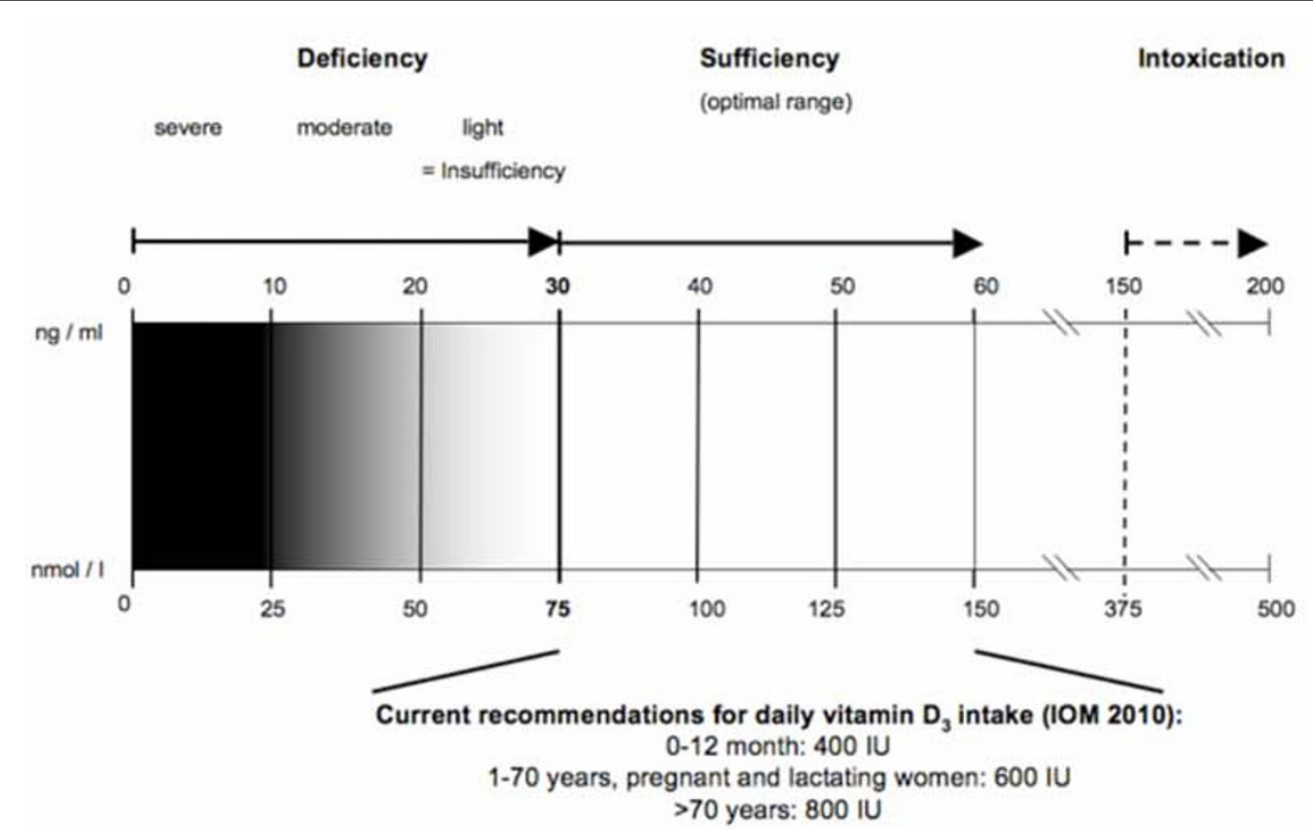

Figure 2 Classification of vitamin D status and recommendations for substitution.

malignancies, are emerging concomitantly with the appreciation of a global pandemic of vitamin D deficiency (Figure 3) $[5,13,14]$. Over the past decade the physiological role of $1 \alpha, 25(\mathrm{OH})_{2} \mathrm{D}_{3}$ has been investigated extensively [15], but data regarding its role in human reproduction are scarce [16-18]. Since the VDR and $1 \alpha$-hydroxylase are expressed in reproductive tissues including ovary, uterus, placenta, testis and hypophysis an association with vitamin $\mathrm{D}$ and many potential pathways linking vitamin $\mathrm{D}$ to reproductive health outcomes almost suggests itself [19-21].

The aims of this review are to critically summarize the most recent data regarding the association of vitamin $\mathrm{D}$ deficiency and female reproductive outcomes. We searched the PubMed and MEDLINE up to August 20 2011 using combinations of the following keywords: vitamin D deficiency/insufficiency and pregnancy, reproduction, fertility/infertility, polycystic ovary syndrome, endometriosis, preeclampsia, gestational diabetes, preterm birth and bacterial vaginosis. Randomized controlled trials, original papers and review articles are included in the present article.

\section{Health implications of vitamin D deficiency in female reproduction \\ Vitamin $D$ and fertility}

A seasonal distribution in human natural conception and birth rates has been consistently demonstrated, showing a peak conception rate during summer in northern countries with strong seasonal contrast in luminosity [22]. Experimental studies have demonstrated that the ovary is a target organ for $1,25(\mathrm{OH})_{2} \mathrm{D}_{3}$ raising the possibility that this active metabolite of vitamin $D_{3}$ might play a role in modulating ovarian activity [23]. Experiments investigating the significance for fertility and reproductive capacity, demonstrate that $25(\mathrm{OH}) \mathrm{D}_{3}-$ deficient female rats had reduced fertility rates, decreased litter sizes and compromised mating behavior [24]. VDR-null mice showed hypergonadotropic hypogonadism with decreased aromatase activities in the ovary, testis and epididymis, uterine hypoplasia, impaired folliculogenesis; decreased sperm counts, decreased sperm motility and histological abnormalities of the testis [19]. Ablation of $1 \alpha$-hydroxylase in female mice is accompanied by abnormal ovarian follicle development, uterine hypoplasia and infertility similar to VDR knockout mice $[25,26]$. However, when serum calcium and phosphorus were normalized by a rescue diet in the female $1 \alpha$ hydroxylase $-/$ - mice, the defective phenotype including dysfunction in the hypothalamic-pituitary-ovarian axis and ovarian angiogenesis were reversed. The authors conclude that the infertility seen in $1,25(\mathrm{OH})_{2} \mathrm{D}_{3}$-deficient mice is an indirect effect mediated by extracellular calcium and phosphorus and not a direct effect of vitamin D deficiency $[27,28]$. Specific human data in this context is sparse. The first study looking at vitamin D and in vitro-fertilization (IVF) success in 10 healthy women undergoing IVF and embryo transfer found an association of raised oestradiol levels during gonadotrophin-induced ovarian stimulation and a significant increase of serum $1,25(\mathrm{OH})_{2} \mathrm{D}_{3} .(\mathrm{r}=0.787, \mathrm{p}<0.001)$ $[29,30]$. Ozkan et al. recently showed higher pregnancy 


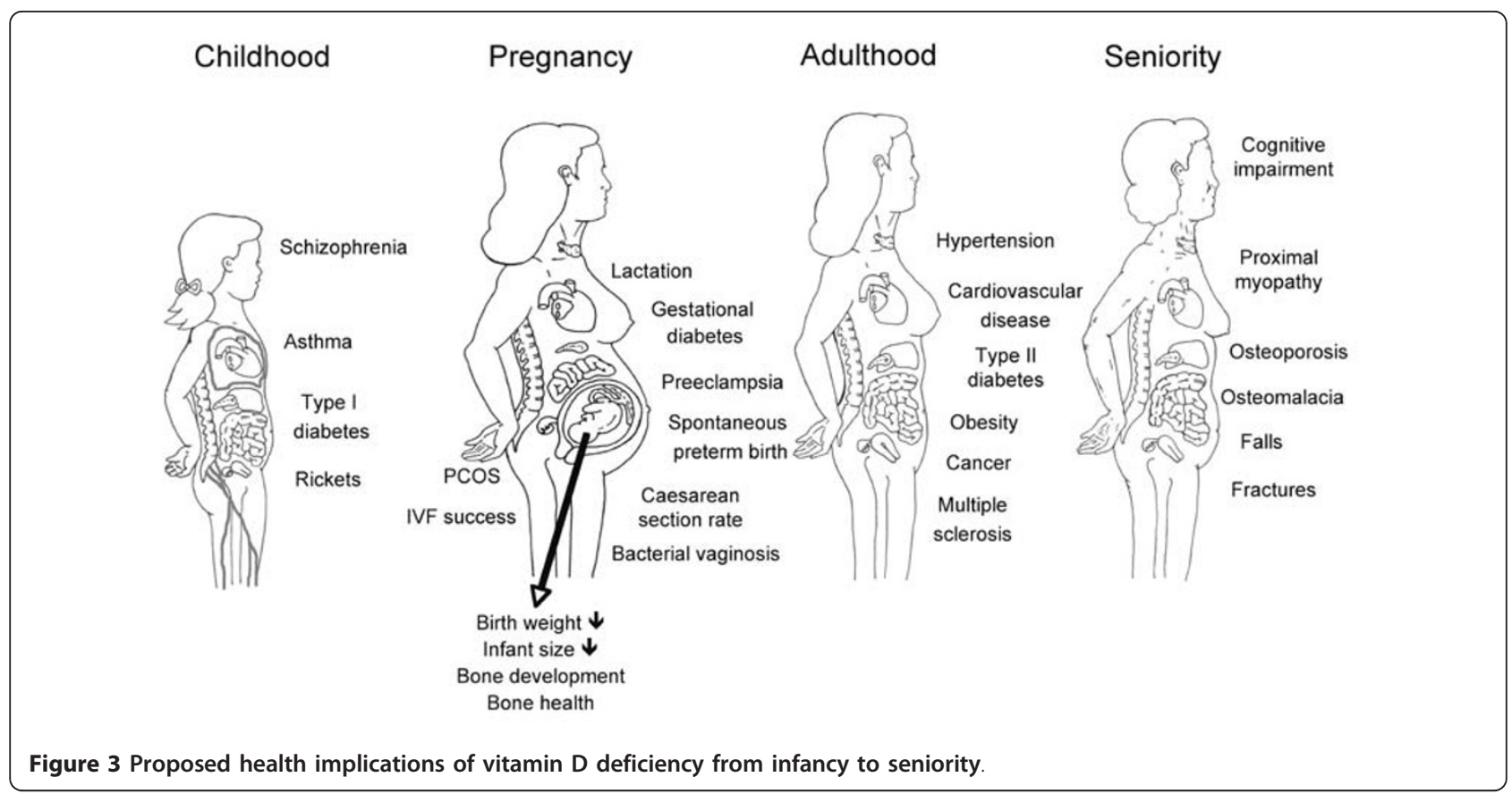

and implantation rates across tertiles of $25(\mathrm{OH}) \mathrm{D}_{3}$ in follicular fluid of 84 infertile women undergoing IVF and proposed follicular fluid $25(\mathrm{OH}) \mathrm{D}_{3}$ levels as an independent predictor to success of an IVF-cycle [31] whereas two prospective studies with 101 and 82 women could not confirm these findings [32,33]. On the contrary no significant differences in pregnancy rates and embryo quality were found between patients with low $(<50 \mathrm{nmol} / \mathrm{l})$ and moderate $(50-75 \mathrm{nmol} /) 25(\mathrm{OH})$ $\mathrm{D}_{3}$ follicular fluid levels, at high vitamin D levels in follicular fluid (> $75 \mathrm{nmol} / \mathrm{l}$ ) even a decrease in pregnancy rate and embryo quality was seen $[32,33]$. It was also shown that increased follicular fluid $25(\mathrm{OH}) \mathrm{D}_{3}$ levels in combination with decreased follicular fluid glucose levels have a negative impact on embryo quality and therefore on IVF outcome [33]. Moreover, Estes and colleagues found a decreased expression of DBP in the follicular fluid of the IVF success group [34]. While the results of human studies are contradictory the role of vitamin D on human fertility and reproductive physiology merits further assessment by appropriate longitudinal studies.

\section{Vitamin $D$ and polycystic ovary syndrome}

Polycystic ovary syndrome (PCOS) is among the most common endocrine disorders in women of reproductive age and has a strong genetic component. It is characterized by ovarian dysfunction and its clinical manifestations may include obesity, increased insulin resistance and compensatory hyperinsulinemia, oligo-/anovulation and infertility [35]. Studies regarding vitamin D status in patients with PCOS show an inverse correlation between vitamin D levels and metabolic risk factors, e.g. insulin resistance, BMI, waist-to-hip-ratio, triglycerides, total testosterone and DHEAS and a positive correlation with insulin sensitivity [36-38]. Data on the role of gene variants involved in vitamin D metabolism in PCOS are sparse but suggest an association of VDR and vitamin D level-related variants with metabolic and endocrine parameters in women with PCOS [39]. Several studies although limited by modest sample sizes have suggested associations between VDR polymorphisms and the development of PCOS as well as insulin resistance [39-43]. Different distributions e.g. of VDR Apa-I and Fok-I gene polymorphisms were found in a cohort of 162 women with PCOS and their controls [42]. It seems possible that variants in the VDR through their effect on luteinizing hormone, sex hormone binding globulin levels and testosterone are involved in the pathogenesis of PCOS $[39,40]$. Further genes involved in vitamin D synthesis, hydroxylation and transport and their role in PCOS are currently under investigation [39].

Clinical trials with either vitamin D supplementation or administration of vitamin $\mathrm{D}_{3}$ analogues showed positive effects on insulin secretion, lipid profile, menstrual cycle and follicular development and a decrease of fasting and stimulated glucose and C-peptide levels [44-48]. However, most of the studies had rather small sample sizes and experimental set-up was quite heterogenous. One of the great confounders in all studies was the presence of obesity. In some studies an association of vitamin $\mathrm{D}$ and insulin resistance was only seen in obese patients or $25(\mathrm{OH}) \mathrm{D}_{3}$ levels were only associated with 
obesity and insulin resistance but not with PCOS per se $[36,49,50]$. Lower serum levels of $25(\mathrm{OH}) \mathrm{D}_{3}$ were shown in obese PCOS patients (e.g. $31.9 \pm 9.4 \mathrm{nmol} / \mathrm{l}$ ) than in non-obese $(73.1 \pm 20.2 \mathrm{nmol} / \mathrm{l})[36,51]$. Consequently, the association of hypovitaminosis $\mathrm{D}$ with features of PCOS may be associated with obesity but not with the presence of PCOS. Recently it was hypothesized that vitamin $\mathrm{D}$ deficiency is not only in association with obesity but a potentially reason [52]. As vitamin D supplementation evidently has positive effects on the outcome of PCOS the question whether to substitute patients with PCOS to ameliorate insulin resistance and prevent other health complications, such as diabetes mellitus type 2, has to be addressed in large intervention trials.

\section{Vitamin $D$ and endometriosis}

An impairment of immunologic mechanism and inflammatory responses has been suggested to be involved in the pathogenesis of endometriosis. Cyclic and early pregnant endometrium is an extrarenal site of vitamin $\mathrm{D}$ synthesis and action [21]. In endometriosis patients the gene encoding for $1 \alpha$-hydroxylase shows an enhanced expression in ectopic endometrium [21]. Recent data also indicate that women suffering from endometriosis express more VDRs in their endometrial tissue [53] and have higher serum levels of $25(\mathrm{OH}) \mathrm{D}_{3}$ than those of the control group $[54,55]$. An analysis of VDR gene polymorphisms (ApaI, TaqI, FokI, BmsI) including 132 women with endometriosis and 133 controls found relatively similar VDR polymorphism genotype frequencies in cases and controls [56]. A small observational study in 26 women with and 17 women without endometriosis detected insignificantly higher serum and lower peritoneal DBP concentrations [57]. However, Faserl and colleagues found about 3 times higher DBP levels associated with the $\mathrm{GC}^{*} 2$ allele product that was in greater concentration in serum pools, as well as in single validation samples in 56 women with endometriosis compared to healthy controls. This finding may be explained by an influence of vitamin D on local activity of immune cells and cytokines maintaining endometriosis and an insufficiency to activate macrophage's phagocytotic function in those carrying the $\mathrm{GC}^{*} 2$ polymorphism [58,59].

\section{Vitamin $D$ and hypertensive disorders of pregnancy}

Hypertensive disorders of pregnancy and especially preeclampsia (PE) are the most studied reproductive health outcomes in association with maternal vitamin D status. The syndrome PE is defined as the occurrence of hypertension and proteinuria after 20 weeks of gestation, and with a prevalence of $3-5 \%$ of all pregnancies worldwide it is the leading cause of maternal and fetal morbidity and mortality [60]. Seasonal patterns in PE suggest a role for vitamin $D$ and sunlight, because of a higher incidence in winter and a lower incidence in summer
[61,62]. Compared with normal pregnancies, PE is characterized by marked changes in vitamin $\mathrm{D}$ and calcium metabolism [63] and already in the early 1990's a role for vitamin D in the pathogenesis of PE was hypothesized [64]. Women with PE are known to have lower circulating $25(\mathrm{OH}) \mathrm{D}_{3}$ levels than normotensive pregnant women [65-68].

In nested case-control studies vitamin $\mathrm{D}$ deficiency in pregnancy $<50 \mathrm{nmol} / \mathrm{l}$ of $25(\mathrm{OH}) \mathrm{D}_{3}$ was associated with an almost 4-fold odds of severe PE [69] and vitamin D deficiency $<37.5 \mathrm{nmol} / \mathrm{l}$ was even associated with a 5fold risk of developing PE [65]. Bodnar et al. showed that $25(\mathrm{OH}) \mathrm{D}_{3}$ deficiency before 22 weeks of gestation is an independent risk factor for the manifestation of $\mathrm{PE}$ [65]. Interestingly, Robinson and colleagues recently reported lower maternal $25(\mathrm{OH}) \mathrm{D}_{3}$ concentrations in 56 women with early onset PE and small for gestational age (SGA) infants vs. infants with normal fetal growth suggesting an impact of vitamin $\mathrm{D}$ on fetal growth through placental mechanisms [70]. In a case-control study in 78 women near term with at least two blood pressure readings above $140 / 90 \mathrm{mmHg}$ and 109 controls, women with low circulating $25(\mathrm{OH}) \mathrm{D}_{3}$ concentrations were more likely to have hypertension [71]. In an earlier study hypertensive pregnant women were not different from the normotensive ones regarding plasma corrected calcium and phosphate and urinary excretion of calcium and phosphate, but had lower total and free calcitriol index (ratio of total calcitriol on DBP) [72].

Not all of the data regarding vitamin D status and PE prevalence are consistent and studies reporting no relationship have significantly lower case numbers [73-75].

While studies in the second and third trimester of pregnancy suggest and association of hypovitaminosis D and PE risk a nested-case control study conducted by Powe et al. in first trimester found that total and free 25 $(\mathrm{OH}) \mathrm{D}_{3}$ levels were not independently associated with subsequent PE [75] and a recent prospective cohort study of 221 Canadian women with high risk of PE found no difference in the rates of PE, gestational hypertension, preterm birth or composite adverse pregnancy outcomes by $25(\mathrm{OH}) \mathrm{D}_{3}$ concentration [74]. The cited studies on vitamin D and PE are not only conducted in different populations but also differ considerably in their experimental set-up, definition of vitamin D deficiency, inclusion criteria and possible confounders so that the discrepancy in study results can not easily be explained and large-scale clinical trials are awaited to clarify this issue. However, vitamin D supplementation studies to prevent PE showed protective effects of vitamin D. The first known study in this context was a controlled trial in London in the 1940's -1950's with 5644 women in which a reduction of $31.5 \%$ in PE was seen in women who received a dietary supplement containing vitamins 
(2,500 IU vitamin D), minerals and fish oil in comparison to the control group who did not receive any supplement [76]. A recent study by Haugen et al. in a cohort of 23,423 nulliparous women in Norway showed a $27 \%$ reduction in the risk of PE in women who took 400-600 IU vitamin D supplements per day compared to women without supplementation [77]. One small RCT conducted in India, however finds no association of vitamin D supplementation (1,200 IU vitamin D/day and $375 \mathrm{mg}$ calcium/day) with a reduced risk for PE but a reduction in diastolic blood pressure of $8 \mathrm{mmHg}$ [78]. In a unique investigation in a Finish birth cohort, Hypponen et al. observed that vitamin D supplementation early in the first year of life is associated with a $50 \%$ reduction of PE prevalence in the first pregnancy later in life [79]. This suggests that vitamin D intake in infancy may be involved in programming processes of the immune system.

It remains unclear how vitamin D insufficiency or deficiency might be involved in pathophysiologic processes that cause PE but it may be linked with PE through actions outside of its traditional calcium regulatory role. One mechanism suggested is the regulation of maternal and placental immunological and inflammatory responses, as it has been shown in experimental models $[80,81]$. The placenta itself expresses $1 \alpha$-hydroxylase and thus produces the active metabolite $1 \alpha, 25(\mathrm{OH})_{2} \mathrm{D}_{3}$ [82]. Whether this placental production of vitamin $\mathrm{D}$ is a major contributor to the maternal vitamin $\mathrm{D}$ status or has mainly paracrine functions is controversial $[83,84]$. In syncytiotrophoblasts from preeclamptic pregnancies the expression and activity of $1 \alpha$-hydroxylase are restricted suggesting an important role for vitamin $D$ at the placental site of the disease [85]. There is evidence that vitamin $\mathrm{D}$ regulates key target genes associated with implantation, trophoblast invasion and implantation tolerance [86]. Regarding implantation tolerance, Th2 cell induction is one of the critical steps required for the maintenance of normal pregnancy whereas impaired implantation and adverse reaction of maternal metabolism to the fetus in PE is mediated by Th1-cytokines [87]. This fetal placental interface may be influenced by vitamin $D$, which has an important role in promoting the shift to a Th2-dominated immune response pattern [88]. The maternal response to reduced placental perfusion in PE may equally be affected by vitamin D. Maternal vitamin D deficiency may lead to the increased inflammatory response that characterizes $\mathrm{PE}$ as well as to endothelial dysfunction through direct effects on angiogenesis gene transcription, including vascular endothelial growth factor (VEGF) [89,90].

Vitamin $D$ and gestational diabetes mellitus

Gestational diabetes (GDM) is becoming increasingly more common and has long-term implications for the health of mothers and their children. The former have an increased risk of developing type 2 diabetes, while their offspring have an increased risk of obesity and diabetes later in life [91]. Polymorphisms of vitamin D have been associated with metabolic mechanisms, e.g. insulin release and the maintenance of glucose tolerance [92]. A genetic contribution of CYP27B1 polymorphisms may modulate $25(\mathrm{OH}) \mathrm{D}_{3}$ levels in GDM patients as reported by Ramos-Lopez et al. [93]. GDM in relation to maternal vitamin $\mathrm{D}$ status is examined only in observational studies [94-100]. In a nested case-control study $25(\mathrm{OH})$ $\mathrm{D}_{3}$ levels $<50 \mathrm{nmol} / \mathrm{l}$ at 16 weeks gestation before the onset of GDM was associated with a 2.7 -fold increased risk for the development of GDM later in pregnancy independent of measured confounders [96]. At the time of oral glucose tolerance testing at mid gestation two reports noted significantly positive correlations between $25(\mathrm{OH}) \mathrm{D}_{3}$ concentrations and insulin sensitivity $[94,98]$ or fasting/2-hour blood glucose levels and $\mathrm{HbA}(1 \mathrm{c})$ [100] whereas no association was observed in another large study in South India [99]. In another recent study the prevalence of severe vitamin D deficiency $(25(\mathrm{OH})$ $\left.\mathrm{D}_{3}<37.5 \mathrm{nmol} / \mathrm{l}\right)$ in the second trimester of pregnancy was higher in GDM compared to normoglycemic pregnant women [95].

Interestingly, after $1,25(\mathrm{OH})_{2} \mathrm{D}_{3}$ supplementation a decrease in glucose and insulin levels was noted [101]. Lau and colleagues contribute to this evidence by demonstrating that, in women with GDM a lower serum $25(\mathrm{OH}) \mathrm{D}_{3}$ concentration was independently associated with poorer glycemic control [100]. RCTs of vitamin D supplementation, initiated early in pregnancy, are now required to demonstrate whether vitamin D supplementation might reduce the incidence or severity of GDM.

\section{Vitamin $D$ and mode of delivery}

Data from Merewood et al. show an inverse association with having a primary cesarean section and vitamin D status in 253 women. Severely vitamin D deficient women with levels of $25(\mathrm{OH}) \mathrm{D}_{3}<37.5 \mathrm{nmol} / \mathrm{l}$ delivered nearly four times as often by cesarean section than those with $37.5 \mathrm{nmol} / \mathrm{l}$ or greater (OR 3.84) [102]. No association was found between obstructed labor ensuing cesarean section and vitamin D status in a case-control study (37 cases, 80 controls) of nulliparous women at term in Pakistan [103]. These are the only studies so far examining vitamin $\mathrm{D}$ status in pregnancy and mode of delivery and therefore the issue needs further investigation.

\section{Vitamin $D$ and spontaneous preterm birth}

Spontaneous preterm birth (SPB) occurs before 37 weeks gestation. From a pathophysiological point of view there are numerous reasons for SPB including intrauterine infection and inflammation. One major 
factor is the presence of bacterial vaginosis, a disruption of the normal balance of vaginal flora with increased growth of anaerobic bacteria responsible for the release of inflammatory cytokines, prostaglandins, and phospholipase $A_{2}$ [104-106]. A recent study by Bodnar et al. showed a linear inverse dose-response association between maternal vitamin $\mathrm{D}$ status and the prevalence of bacterial vaginosis in early pregnancy [107]. Using a large, representative data set with inclusion of 3,523 women Hensel et al confirmed the association of 25 $(\mathrm{OH}) \mathrm{D}_{3}$ deficiency $(<75 \mathrm{nmol} / \mathrm{l})$ and bacterial vaginosis among pregnant women [108]. In a cross-sectional study of African American adolescents bacterial vaginosis was shown to also be associated with vitamin D insufficiency $\left(25(\mathrm{OH}) \mathrm{D}_{3}<50 \mathrm{nmol} / \mathrm{l}\right)$ [109].

Since vitamin D has immunmodulatory and antiinflammatory effects, such as the regulation of production and function of cytokines and neutrophil degranulation products that is important and relevant to prevent microbial invasion one may expect a protective effect on SPB risk [110-112]. The various cells of the immune system express VDRs and are modulated by vitamin D [113]. Although vitamin D action dampens the activation of the acquired immune system in response to autoimmunity, this hormone has key actions that enhance the innate immune system. It is involved in cell-mediated immunity by reducing the production of inflammatory cytokines such as IL-1, 6 and TNF $\alpha$ that are involved in SPB $[89,110,114,115]$. Human decidual cells are able to synthesize active $1,25(\mathrm{OH})_{2} \mathrm{D}_{3}$. Therefore several studies point to the fact that vitamin $\mathrm{D}$ is involved in the regulation of acquired and innate immune responses at the fetal-maternal interface across gestation $[89,110,116]$. Vitamin D might reduce the risk of SPB also by helping to maintain myometrial quiescence. Myometrial contractility is dependent on calcium release within the muscle cell and this process is regulated by vitamin D $[117,118]$. Although experimental data are promising there is limited observational data available on the relationship of vitamin D and SPB. A recent prospective cohort study in 221 Canadian women could not show an association of $25(\mathrm{OH}) \mathrm{D}_{3}$ deficiency (<50 nmol/l) or insufficiency $(<75 \mathrm{nmol} / \mathrm{l})$ with preterm birth [74] whereas in another observational study with 14 cases maternal $25(\mathrm{OH}) \mathrm{D}_{3}$ levels of $<28 \mathrm{nmol} / \mathrm{l}$ at 28 to 32 weeks of gestation were associated with a 0.7 weeks shorter gestation in an all Caucasian sample but not at 11 weeks gestation [119]. In another first trimester cohort of 4,225 women with 40 cases of SPB $\leq 34$ $6 / 7$ weeks the prevalence of vitamin D deficiency (25 $\left.(\mathrm{OH}) \mathrm{D}_{3}<50 \mathrm{nmol} / \mathrm{l}\right)$ was comparable among women who subsequently delivered preterm compared with controls [120]. 25(OH)D $\mathrm{D}_{3}$ levels $<80 \mathrm{nmol} / \mathrm{l}$ in HIVpositive pregnant Tanzanian women were not associated with an increased risk for preterm delivery [121]. In a cohort of 82,213 singleton live births Bodnar et al. found indirect evidence that vitamin $D$ and seasonal sunlight exposure are relevant for preterm birth. The prevalence of SPB was lowest among women who conceived in summer and fall and was highest among winter and spring conceptions [61,122]. The strongest evidence that vitamin $\mathrm{D}$ sufficiency may protect against preterm birth may be reported in the near future by Hollis and colleagues from a randomized controlled trial of 600 white, black, and Hispanic mothers and supplementation of $400 \mathrm{IU}, 2,000 \mathrm{IU}$, or 4,000 IU/d of vitamin $\mathrm{D}_{3}$ in early pregnancy [123]. More large studies are awaited to validate these important findings that might represent vitamin $\mathrm{D}$ supplementation as a simple and inexpensive method to reduce the risk of this adverse pregnancy outcome.

\section{Vitamin $D$ and other reproductive outcomes}

Vitamin D seems to have a complex relation with fetal growth that may vary by genotype, race and other variables that could not be identified yet. This relation between maternal vitamin $\mathrm{D}$ status and fetal birth weight has been studied in RCT's [124-127] and a number of observational studies [15,99,119,128-135] with mixed results. Due to confounding factors (e.g. maternal nutritional status, calcium and phosphorus intake, maternal prepregnant BMI, socioeconomic status), that were not always considered in these analyses the outcomes are hard to compare.

Despite the recognized role of vitamin D in bone metabolism and prevention of osteoporosis in postmenopausal women, the information available on the impact of vitamin D status on maternal and fetal bone health is limited. No systemic studies have examined the effect of vitamin $\mathrm{D}$ status in the neonate on skeletal mineral content in humans, particularly studies regarding isolated vitamin D effects clearly separated from calcium effects are very rare. Only a handful of observational studies [119,128,131,136-139] and one RCT [124] reported contradictory results. Therefore the importance of maternal vitamin D status to fetal skeletal development is not sufficiently investigated. Nevertheless we would like to point the interested reader to well-written reviews of the above-mentioned topics [16,140,141].

Breast milk is an ideal nutrient for a newborn but is not sufficient to maintain newborn vitamin D levels within a normal range. Many nursing mothers or their infants require vitamin D supplementation for optimal health. Because of the existence of well-written reviews analyzing the available literature on vitamin D and lactation we refer the reader to these articles [140,142-144].

\section{Vitamin $D$ and fetal programming}

Vitamin D induces more than 3,000 genes, many of which have a role in fetal development [145]. Therefore, 
vitamin D may be particular relevant to the "developmental origins" or "fetal programming hypothesis" in which environmental factors such as vitamin D influence the genomic programming of fetal and neonatal developmental and subsequent disease risk in both childhood and adult life [146]. Interestingly, in later life, children of mothers with low vitamin D serum levels during pregnancy suffer more often from chronic diseases such as wheezing and asthma [147-149], schizophrenia [150,151], multiple sclerosis [152], type 1 diabetes mellitus and insulin resistance [153-158] suggesting intrauterine programming as possible mechanism $[17,143,159,160]$. Mechanisms underlying this longterm effect of the intrauterine environment are not known yet but epigenetic mechanisms that lead to persistent changes in structure and function in endocrine systems are hypothesized.

\section{Vitamin $D$ supplementation and toxicity issues}

Although summer sunlight is the most potent source of vitamin $\mathrm{D}$, fortified foods or specific supplements take on an increasing importance, especially in the winter at northern latitudes $\left(40^{\circ} \mathrm{N}\right)$. Dietary recommendations are available in many European countries, the US and also globally $[161,162]$. The updated dietary reference intakes for calcium and vitamin D of the IOM published for the US and Canada (e.g. IOM 600 IU for pregnant/lactating women) are based primarily on the intake of vitamin $\mathrm{D}$ to ensure skeletal health (Figure 2). Levels of $25(\mathrm{OH}) \mathrm{D}_{3}$ of 75-110 nmol/l provided optimal benefits for these outcomes and can be obtained with daily doses of 1,800-4,000 IU [163,164]. Concerning optimal concentrations of $25(\mathrm{OH}) \mathrm{D}_{3}$ the IOM link serum $25(\mathrm{OH}) \mathrm{D}_{3}$ levels $\geq 50 \mathrm{nmol} / \mathrm{l}$ with the Recommended Dietary Allowance that meets $97,5 \%$ of the US population's needs and a level of $<30 \mathrm{nmol} / \mathrm{l}$ with increased risk for vitamin D-deficient rickets [162]. Supraphysiologic, potentially toxic levels are defined as a $25(\mathrm{OH}) \mathrm{D}_{3}$ concentration above $150 \mathrm{nmol} / \mathrm{l}$ [5].

The optimal serum levels and intake for pregnancy are not known $[160,165]$. While low doses of 400, 800 and 1,600 IU did little to improve vitamin D nutritional status in pregnant women [126] in a very recent randomized controlled trial vitamin D supplementation of 4,000 IU/d started at 12-16 weeks of gestation was safe and most effective achieving sufficient levels in women and their neonates regardless of race [166]. As with other micronutrients, both low and excessively high intakes of vitamin D are associated with increased risk of adverse effects and long term outcomes of clinical trials will provide more information on the safety of relatively high levels of $25(\mathrm{OH}) \mathrm{D}_{3}$.

\section{Conclusions}

Vitamin D deficiency is still considered a problem of the past by health care professionals and the public. Populations at risk include infants, children, pregnant and postmenopausal women. We have reviewed the existing evidence for a range of possible adverse health outcomes during a women's reproductive period that may relate to low vitamin D status. Besides the classical diseases such as rickets, osteoporosis and osteomalacia, vitamin D deficiency in women might be associated with lower fertility and an increased risk for adverse pregnancy outcomes. Most of the findings in humans are associations or based on animal and laboratory studies and can therefore not determine causality. Available scientific data are limited and well-conducted clinical trials are still lacking. Contradictory results can be explained not only by methodological differences. Genetic, ethnic and racial differences as well as latitude of residence and season may account to the observed discrepancies in several reproductive health outcomes. Vitamin D deficiency is often clinically unrecognized, however laboratory measurements are easy to perform, and treatment of vitamin D deficiency is inexpensive. Oral supplementation is the best-tolerated and the most effective route of administration. At this point optimal levels of $25(\mathrm{OH})$ $\mathrm{D}_{3}$ for the non-classical actions of vitamin $\mathrm{D}$ in the reproductive period are not clear. Pressing questions awaiting an answer include the optimal level of vitamin $\mathrm{D}$ in women during their reproductive period and especially in pregnancy to achieve maximal benefit for mother and fetus and whether vitamin D supplementation started preconceptionally is protective against preeclampsia and other adverse pregnancy outcomes. High quality, large-scale RCTs are required to determine the optimal $25(\mathrm{OH}) \mathrm{D}_{3}$ levels in the reproductive period and the amount of vitamin $\mathrm{D}$ supplementation required to achieve those levels for the numerous actions of vitamin D throughout a woman's life. Confirmation of experimental observations relating to the risk of vitamin D deficiency would have important public health implications.

\section{Abbreviations \\ CYP27B1: 1a-hydroxylase; DBP: vitamin D-binding protein; GDM: gestational diabetes; IOM: Institute of Medicine; IVF: in vitro-fertilization; PCOS: polycystic ovary syndrome; PTH: parathyroid hormone; PE: preeclampsia; RCT: \\ randomized clinical trial; SPB: spontaneous preterm birth; VDR: vitamin D receptor}

\section{Acknowledgements}

We thank Mrs. Friederike Ritter for her support creating figure 3 and Robert Powers, PhD and Carl Hubel PhD, Magee-Womens Research Institute, Pittsburgh, PA, for their helpful suggestions concerning this manuscript. 


\section{Authors' contributions}

All authors have made substantial contributions to conception and design of the manuscript and have been involved in drafting the manuscript and have given final approval of the version to be published. Both authors read and approved the final manuscript.

\section{Competing interests}

The authors declare that they have no competing interests.

Received: 13 September 2011 Accepted: 2 November 2011

Published: 2 November 2011

\section{References}

1. Alpert PT, Shaikh U: The effects of vitamin D deficiency and insufficiency on the endocrine and paracrine systems. Biol Res Nurs 2007, 9(2):117-129.

2. Jones G, Strugnell SA, DeLuca HF: Current understanding of the molecular actions of vitamin D. Physiol Rev 1998, 78(4):1193-1231.

3. Holick MF: Vitamin D status: measurement, interpretation, and clinical application. Ann Epidemiol 2009, 19(2):73-78.

4. Zerwekh JE: Blood biomarkers of vitamin D status. Am J Clin Nutr 2008, 87(4):1087S-1091S.

5. Holick MF: Vitamin D deficiency. N Engl J Med 2007, 357(3):266-281.

6. Hollis BW: Circulating 25 -hydroxyvitamin D levels indicative of vitamin D sufficiency: implications for establishing a new effective dietary intake recommendation for vitamin D. J Nutr 2005, 135(2):317-322.

7. Dawson-Hughes B, Heaney RP, Holick MF, Lips P, Meunier PJ, Vieth R: Estimates of optimal vitamin D status. Osteoporos Int 2005, 16(7):713-716.

8. Nutrition and bone health: with particular reference to calcium and vitamin D. Report of the Subgroup on Bone Health, Working Group on the Nutritional Status of the Population of the Committee on Medical Aspects of the Food Nutrition Policy. Rep Health Soc Subj (Lond) 1998, 49: iii-xvii, 1-24.

9. Bodnar LM, Simhan HN, Powers RW, Frank MP, Cooperstein E, Roberts JM: High prevalence of vitamin $D$ insufficiency in black and white pregnant women residing in the northern United States and their neonates. J Nutr 2007, 137(2):447-452

10. Holmes VA, Barnes MS, Alexander HD, McFaul P, Wallace JM: Vitamin D deficiency and insufficiency in pregnant women: a longitudinal study. $\mathrm{Br}$ J Nutr 2009, 102(6):876-881.

11. Johnson DD, Wagner CL, Hulsey TC, MCNeil RB, Ebeling M, Hollis BW: Vitamin $D$ deficiency and insufficiency is common during pregnancy. Am J Perinatol 2011, 28(1):7-12.

12. Datta S, Alfaham M, Davies DP, Dunstan F, Woodhead S, Evans J, Richards B: Vitamin D deficiency in pregnant women from a nonEuropean ethnic minority population-an interventional study. BJOG 2002, 109(8):905-908

13. Heaney RP: Vitamin D in health and disease. Clin J Am Soc Nephrol 2008, 3(5):1535-1541.

14. Perez-Lopez FR, Chedraui P, Fernandez-Alonso AM: Vitamin D and aging: beyond calcium and bone metabolism. Maturitas 2011, 69(1):27-36.

15. Mannion CA, Gray-Donald K, Koski KG: Association of low intake of milk and vitamin $D$ during pregnancy with decreased birth weight. CMAJ 2006, 174(9):1273-1277.

16. Lewis S, Lucas RM, Halliday J, Ponsonby AL: Vitamin D deficiency and pregnancy: From preconception to birth. Mol Nutr Food Res 2010, 54:1092-1102.

17. Lucas RM, Ponsonby AL, Pasco JA, Morley R: Future health implications of prenatal and early-life vitamin D status. Nutr Rev 2008, 66(12):710-720.

18. Perez-Lopez FR: Vitamin D: the secosteroid hormone and human reproduction. Gynecol Endocrinol 2007, 23(1):13-24.

19. Kinuta $K$, Tanaka $H$, Moriwake $T$, Aya $K$, Kato $S$, Seino $Y$ : Vitamin $D$ is an important factor in estrogen biosynthesis of both female and male gonads. Endocrinology 2000, 141(4):1317-1324.

20. Hurley WL, Doane RM: Recent developments in the roles of vitamins and minerals in reproduction. J Dairy Sci 1989, 72(3):784-804.

21. Vigano P, Lattuada D, Mangioni S, Ermellino L, Vignali M, Caporizzo E, Panina-Bordignon P, Besozzi M, Di Blasio AM: Cycling and early pregnant endometrium as a site of regulated expression of the vitamin $D$ system. J Mol Endocrinol 2006, 36(3):415-424.

22. Rojansky N, Brzezinski A, Schenker JG: Seasonality in human reproduction: an update. Hum Reprod 1992, 7(6):735-745.
23. Dokoh S, Donaldson CA, Marion SL, Pike JW, Haussler MR: The ovary: a target organ for 1,25-dihydroxyvitamin D3. Endocrinology 1983, 112(1):200-206.

24. Halloran BP, DeLuca HF: Effect of vitamin D deficiency on fertility and reproductive capacity in the female rat. J Nutr 1980, 110(8):1573-1580.

25. Panda DK, Miao D, Tremblay ML, Sirois J, Farookhi R, Hendy GN, Goltzman D: Targeted ablation of the 25-hydroxyvitamin D 1alpha -hydroxylase enzyme: evidence for skeletal, reproductive, and immune dysfunction. Proc Natl Acad Sci USA 2001, 98(13):7498-7503.

26. Yoshizawa T, Handa Y, Uematsu Y, Takeda S, Sekine K, Yoshihara Y, Kawakami T, Arioka K, Sato H, Uchiyama Y, Masushige S, Fukamizu A, Matsumoto T, Kato S: Mice lacking the vitamin D receptor exhibit impaired bone formation, uterine hypoplasia and growth retardation after weaning. Nat Genet 1997, 16(4):391-396.

27. Sun W, Xie H, Ji J, Zhou X, Goltzman D, Miao D: Defective female reproductive function in 1,25(OH)2D-deficient mice results from indirect effect mediated by extracellular calcium and/or phosphorus. Am J Physiol Endocrinol Metab 2010, 299(6):E928-935.

28. Johnson $L E$, DeLuca HF: Vitamin $D$ receptor null mutant mice fed high levels of calcium are fertile. J Nutr 2001, 131(6):1787-1791.

29. Potashnik G, Lunenfeld E, Levitas E, Itskovitz J, Albutiano S, Yankowitz N, Sonin Y, Levy J, Glezerman M, Shany S: The relationship between endogenous oestradiol and vitamin D3 metabolites in serum and follicular fluid during ovarian stimulation for in-vitro fertilization and embryo transfer. Hum Reprod 1992, 7(10):1357-1360.

30. Wehr E, Pilz S, Boehm BO, Marz W, Obermayer-Pietsch B: Association of vitamin D status with serum androgen levels in men. Clin Endocrinol (Oxf) 2010, 73(2):243-248.

31. Ozkan S, Jindal S, Greenseid K, Shu J, Zeitlian G, Hickmon C, Pal L: Replete vitamin $D$ stores predict reproductive success following in vitro fertilization. Fertil Steril 2010, 94(4):1314-1319.

32. Anifandis GM, Dafopoulos K, Messini Cl, Chalvatzas N, Liakos N, Pournaras S, Messinis IE: Prognostic value of follicular fluid $25-\mathrm{OH}$ vitamin $\mathrm{D}$ and glucose levels in the IVF outcome. Reprod Biol Endocrinol 2010, 8:91.

33. Aleyasin A, Hosseini MA, Mahdavi A, Safdarian L, Fallahi P, Mohajeri MR, Abbasi M, Esfahani F: Predictive value of the level of vitamin $D$ in follicular fluid on the outcome of assisted reproductive technology. Eur J Obstet Gynecol Reprod Biol 2011.

34. Estes SJ, Ye B, Qiu W, Cramer D, Hornstein MD, Missmer SA: A proteomic analysis of IVF follicular fluid in women $<$ or $=32$ years old. Fertil Steril 2009, 92(5):1569-1578.

35. Revised 2003 consensus on diagnostic criteria and long-term health risks related to polycystic ovary syndrome (PCOS). Hum Reprod 2004, 19(1):41-47.

36. Yildizhan R, Kurdoglu M, Adali E, Kolusari A, Yildizhan B, Sahin HG, Kamaci M: Serum 25-hydroxyvitamin D concentrations in obese and non-obese women with polycystic ovary syndrome. Arch Gynecol Obstet 2009, 280(4):559-563.

37. Wehr E, Pilz S, Schweighofer N, Giuliani A, Kopera D, Pieber TR, ObermayerPietsch B: Association of hypovitaminosis D with metabolic disturbances in polycystic ovary syndrome. Eur J Endocrinol 2009, 161(4):575-582.

38. Li HW, Brereton RE, Anderson RA, Wallace AM, Ho CK: Vitamin D deficiency is common and associated with metabolic risk factors in patients with polycystic ovary syndrome. Metabolism 2011, 60(10):1475-1481.

39. Wehr E, Trummer O, Giuliani A, Gruber HJ, Pieber TR, Obermayer-Pietsch B: Vitamin D-associated polymorphisms are related to insulin resistance and vitamin $\mathrm{D}$ deficiency in polycystic ovary syndrome. Eur J Endocrinol 2011, 164(5):741-749.

40. Ranjzad F, Mahban A, Irani Shemirani A, Mahmoudi T, Vahedi M, Nikzamir A, Zali MR: Influence of gene variants related to calcium homeostasis on biochemical parameters of women with polycystic ovary syndrome. $J$ Assist Reprod Genet 2010, 28:225-232.

41. Ranjzad F, Mahmoudi T, Irani Shemirani A, Mahban A, Nikzamir A, Vahedi M, Ashrafi M, Gourabi H: A common variant in the adiponectin gene and polycystic ovary syndrome risk. Mol Biol Rep 2011.

42. Mahmoudi T: Genetic variation in the vitamin D receptor and polycystic ovary syndrome risk. Fertil Steril 2009, 92(4):1381-1383.

43. Chiu KC, Chuang LM, Yoon C: The vitamin D receptor polymorphism in the translation initiation codon is a risk factor for insulin resistance in glucose tolerant Caucasians. BMC Med Genet 2001, 2:2. 
44. Rashidi B, Haghollahi F, Shariat M, Zayerii F: The effects of calcium-vitamin D and metformin on polycystic ovary syndrome: a pilot study. Taiwan J Obstet Gynecol 2009, 48(2):142-147.

45. Thys-Jacobs S, Donovan D, Papadopoulos A, Sarrel P, Bilezikian JP: Vitamin $\mathrm{D}$ and calcium dysregulation in the polycystic ovarian syndrome. Steroids 1999, 64(6):430-435.

46. Kotsa K, Yavropoulou MP, Anastasiou O, Yovos JG: Role of vitamin D treatment in glucose metabolism in polycystic ovary syndrome. Fertil Steril 2009, 92(3):1053-1058.

47. Selimoglu H, Duran C, Kiyici S, Ersoy C, Guclu M, Ozkaya G, Tuncel E, Erturk E, Imamoglu S: The effect of vitamin D replacement therapy on insulin resistance and androgen levels in women with polycystic ovary syndrome. J Endocrinol Invest 2010, 33(4):234-238.

48. Wehr E, Pieber TR, Obermayer-Pietsch B: Effect of vitamin D3 treatment on glucose metabolism and menstrual frequency in PCOS women-a pilot study. J Endocrinol Invest 2011.

49. Hahn S, Haselhorst U, Tan S, Quadbeck B, Schmidt M, Roesler S, Kimmig R, Mann K, Janssen OE: Low serum 25-hydroxyvitamin D concentrations are associated with insulin resistance and obesity in women with polycystic ovary syndrome. Exp Clin Endocrinol Diabetes 2006, 114(10):577-583.

50. Panidis D, Balaris C, Farmakiotis D, Rousso D, Kourtis A, Balaris V, Katsikis I, Zournatzi V, Diamanti-Kandarakis E: Serum parathyroid hormone concentrations are increased in women with polycystic ovary syndrome. Clin Chem 2005, 51(9):1691-1697.

51. Mahmoudi T, Gourabi H, Ashrafi M, Yazdi RS, Ezabadi Z: Calciotropic hormones, insulin resistance, and the polycystic ovary syndrome. Fertil Steril 2010, 93(4):1208-1214.

52. Foss YJ: Vitamin D deficiency is the cause of common obesity. Med Hypotheses 2009, 72(3):314-321.

53. Agic A, Xu H, Altgassen C, Noack F, Wolfler MM, Diedrich K, Friedrich M, Taylor RN, Hornung D: Relative expression of 1,25-dihydroxyvitamin D3 receptor, vitamin D 1 alpha-hydroxylase, vitamin D 24-hydroxylase, and vitamin $D$ 25-hydroxylase in endometriosis and gynecologic cancers. Reprod Sci 2007, 14(5):486-497.

54. Somigliana E, Panina-Bordignon P, Murone S, Di Lucia P, Vercellini P, Vigano $P$ : Vitamin $D$ reserve is higher in women with endometriosis. Hum Reprod 2007, 22(8):2273-2278.

55. Hartwell D, Rodbro P, Jensen SB, Thomsen $K$, Christiansen C: Vitamin D metabolites-relation to age, menopause and endometriosis. Scand J Clin Lab Invest 1990, 50(2):115-121.

56. Vilarino FL, Bianco B, Lerner TG, Teles JS, Mafra FA, Christofolini DM, Barbosa CP: Analysis of vitamin D receptor gene polymorphisms in women with and without endometriosis. Hum Immunol 2011, 72(4):359-363.

57. Borkowski J, Gmyrek GB, Madej JP, Nowacki W, Goluda M, Gabrys M, Stefaniak T, Chelmonska-Soyta A: Serum and peritoneal evaluation of vitamin D-binding protein in women with endometriosis. Postepy Hig Med Dosw (Online) 2008, 62:103-109.

58. Faserl K, Golderer G, Kremser L, Lindner H, Sarg B, Wildt L, Seeber B: Polymorphism in vitamin D-binding protein as a genetic risk factor in the pathogenesis of endometriosis. J Clin Endocrinol Metab 2011, 96(1): E233-241.

59. Sibai B, Dekker G, Kupferminc M: Pre-eclampsia. Lancet 2005, 365(9461):785-799

60. Roberts JM, Lain KY: Recent Insights into the pathogenesis of preeclampsia. Placenta 2002, 23(5):359-372.

61. Bodnar LM, Catov JM, Roberts JM: Racial/ethnic differences in the monthly variation of preeclampsia incidence. Am J Obstet Gynecol 2007, 196(4):324 e321-325.

62. TePoel MR, Saftlas AF, Wallis AB: Association of seasonality with hypertension in pregnancy: a systematic review. J Reprod Immunol 2011, 89(2):140-152.

63. Seely EW, Wood RJ, Brown EM, Graves SW: Lower serum ionized calcium and abnormal calciotropic hormone levels in preeclampsia. J Clin Endocrinol Metab 1992, 74(6):1436-1440.

64. Bourges $\mathrm{H}$, Halhali A: Hypothesis to explain the association between hypocalciuria and low circulating 1,25-dihydroxyvitamin D levels in preeclampsia. Med Hypotheses 1993, 41(3):239-243.

65. Bodnar LM, Catov JM, Simhan HN, Holick MF, Powers RW, Roberts JM: Maternal vitamin D deficiency increases the risk of preeclampsia. J Clin Endocrinol Metab 2007, 92(9):3517-3522.
66. Halhali A, Tovar AR, Torres N, Bourges H, Garabedian M, Larrea F: Preeclampsia is associated with low circulating levels of insulin-like growth factor I and 1,25-dihydroxyvitamin $D$ in maternal and umbilical cord compartments. J Clin Endocrinol Metab 2000, 85(5):1828-1833.

67. August P, Marcaccio B, Gertner JM, Druzin ML, Resnick LM, Laragh JH: Abnormal 1,25-dihydroxyvitamin D metabolism in preeclampsia. Am J Obstet Gynecol 1992, 166(4):1295-1299.

68. Robinson CJ, Alanis MC, Wagner CL, Hollis BW, Johnson DD: Plasma 25hydroxyvitamin $\mathrm{D}$ levels in early-onset severe preeclampsia. Am J Obstet Gynecol 2010, 203(4):366 e361-366.

69. Baker AM, Haeri S, Camargo CA, Espinola JA, Stuebe AM: A Nested CaseControl Study of Midgestation Vitamin D Deficiency and Risk of Severe Preeclampsia. J Clin Endocrinol Metab 2010, 95(11):5105-5109.

70. Robinson CJ, Wagner CL, Hollis BW, Baatz JE, Johnson DD: Maternal vitamin $\mathrm{D}$ and fetal growth in early-onset severe preeclampsia. Am $J$ Obstet Gynecol 2011, 204(6):556 e551-554.

71. Ringrose JS, PausJenssen AM, Wilson M, Blanco L, Ward H, Wilson TW: Vitamin D and hypertension in pregnancy. Clin Invest Med 2011, 34(3): E147-154.

72. Lalau JD, Jans I, el Esper N, Bouillon R, Fournier A: Calcium metabolism, plasma parathyroid hormone, and calcitriol in transient hypertension of pregnancy. Am J Hypertens 1993, $6(6$ Pt 1):522-527.

73. Halhali A, Villa AR, Madrazo E, Soria MC, Mercado E, Diaz L, Avila E, Garabedian M, Larrea F: Longitudinal changes in maternal serum 1,25dihydroxyvitamin $D$ and insulin like growth factor I levels in pregnant women who developed preeclampsia: comparison with normotensive pregnant women. J Steroid Biochem Mol Biol 2004, 89-90(1-5):553-556.

74. Shand AW, Nassar N, Von Dadelszen P, Innis SM, Green TJ: Maternal vitamin $D$ status in pregnancy and adverse pregnancy outcomes in a group at high risk for pre-eclampsia. BJOG 2010, 117(13):1593-1598.

75. Powe CE, Seely EW, Rana S, Bhan I, Ecker J, Karumanchi SA, Thadhani R: First trimester vitamin $D$, vitamin $D$ binding protein, and subsequent preeclampsia. Hypertension 2010, 56(4):758-763.

76. Olsen SF, Secher NJ: A possible preventive effect of low-dose fish oil on early delivery and pre-eclampsia: indications from a 50-year-old controlled trial. Br J Nutr 1990, 64(3):599-609.

77. Haugen M, Brantsaeter AL, Trogstad L, Alexander J, Roth C, Magnus P, Meltzer HM: Vitamin D supplementation and reduced risk of preeclampsia in nulliparous women. Epidemiology 2009, 20(5):720-726.

78. Marya RK, Rathee S, Manrow M: Effect of calcium and vitamin D supplementation on toxaemia of pregnancy. Gynecol Obstet Invest 1987, 24(1):38-42.

79. Hypponen E, Hartikainen AL, Sovio U, Jarvelin MR, Pouta A: Does vitamin D supplementation in infancy reduce the risk of pre-eclampsia? Eur J Clin Nutr 2007, 61(9):1136-1139.

80. Hewison M: Vitamin $\mathrm{D}$ and the immune system: new perspectives on an old theme. Endocrinol Metab Clin North Am 2010, 39(2):365-379, table of contents.

81. Liu NQ, Kaplan AT, Lagishetty V, Ouyang YB, Ouyang Y, Simmons CF, Equils $\mathrm{O}$, Hewison M: Vitamin $\mathrm{D}$ and the regulation of placental inflammation. J Immunol 2011, 186(10):5968-5974.

82. Barrera D, Avila E, Hernandez G, Mendez I, Gonzalez L, Halhali A, Larrea F, Morales A, Diaz L: Calcitriol affects hCG gene transcription in cultured human syncytiotrophoblasts. Reprod Biol Endocrinol 2008, 6:3.

83. Kovacs CS: Vitamin D in pregnancy and lactation: maternal, fetal, and neonatal outcomes from human and animal studies. Am J Clin Nutr 2008, 88(2):520S-528S

84. Delvin EE, Arabian A, Glorieux FH, Mamer OA: In vitro metabolism of 25hydroxycholecalciferol by isolated cells from human decidua. J Clin Endocrinol Metab 1985, 60(5):880-885.

85. Diaz L, Arranz C, Avila E, Halhali A, Vilchis F, Larrea F: Expression and activity of 25-hydroxyvitamin D-1 alpha-hydroxylase are restricted in cultures of human syncytiotrophoblast cells from preeclamptic pregnancies. J Clin Endocrinol Metab 2002, 87(8):3876-3882.

86. Evans KN, Bulmer JN, Kilby MD, Hewison M: Vitamin D and placentaldecidual function. I Soc Gynecol Investig 2004, 11(5):263-271.

87. Saito S, Sakai M: Th1/Th2 balance in preeclampsia. J Reprod Immunol 2003, 59(2):161-173

88. Lemire JM, Archer DC, Beck L, Spiegelberg HL: Immunosuppressive actions of 1,25-dihydroxyvitamin D3: preferential inhibition of Th1 functions. J Nutr 1995, $125(6$ Suppl):1704S-1708S. 
89. Diaz L, Noyola-Martinez N, Barrera D, Hernandez G, Avila E, Halhali A, Larrea F: Calcitriol inhibits TNF-alpha-induced inflammatory cytokines in human trophoblasts. J Reprod Immunol 2009, 81(1):17-24.

90. Cardus A, Panizo S, Encinas M, Dolcet X, Gallego C, Aldea M, Fernandez E, Valdivielso JM: 1,25-dihydroxyvitamin D3 regulates VEGF production through a vitamin $D$ response element in the VEGF promoter. Atherosclerosis 2009, 204(1):85-89.

91. Damm P, Kuhl C, Bertelsen A, Molsted-Pedersen L: Predictive factors for the development of diabetes in women with previous gestational diabetes mellitus. Am J Obstet Gynecol 1992, 167(3):607-616.

92. Hirai M, Suzuki S, Hinokio Y, Hirai A, Chiba M, Akai H, Suzuki C, Toyota T: Variations in vitamin D-binding protein (group-specific component protein) are associated with fasting plasma insulin levels in Japanese with normal glucose tolerance. J Clin Endocrinol Metab 2000, 85(5):1951-1953.

93. Ramos-Lopez E, Kahles H, Weber S, Kukic A, Penna-Martinez M, Badenhoop K, Louwen F: Gestational diabetes mellitus and vitamin D deficiency: genetic contribution of CYP27B1 and CYP2R1 polymorphisms. Diabetes Obes Metab 2008, 10(8):683-685.

94. Maghbooli Z, Hossein-Nezhad A, Karimi F, Shafaei AR, Larijani B: Correlation between vitamin D3 deficiency and insulin resistance in pregnancy. Diabetes Metab Res Rev 2008, 24(1):27-32.

95. Soheilykhah S, Mojibian M, Rashidi M, Rahimi-Saghand S, Jafari F: Maternal vitamin D status in gestational diabetes mellitus. Nutr Clin Pract 2010, 25(5):524-527.

96. Zhang C, Qiu C, Hu FB, David RM, van Dam RM, Bralley A, Williams MA: Maternal plasma 25-hydroxyvitamin D concentrations and the risk for gestational diabetes mellitus. PLoS One 2008, 3(11):e3753.

97. Baker AM, Haeri S, Camargo CA, Stuebe AM, Boggess KA: First trimester maternal vitamin $D$ status and risk for gestational diabetes mellitus: a nested case-control study. Diabetes Metab Res Rev 2011.

98. Clifton-Bligh RJ, McElduff P, McElduff A: Maternal vitamin D deficiency, ethnicity and gestational diabetes. Diabet Med 2008, 25(6):678-684

99. Farrant HJ, Krishnaveni GV, Hill JC, Boucher BJ, Fisher DJ, Noonan K, Osmond C, Veena SR, Fall CH: Vitamin D insufficiency is common in Indian mothers but is not associated with gestational diabetes or variation in newborn size. Eur J Clin Nutr 2009, 63(5):646-652.

100. Lau SL, Gunton JE, Athayde NP, Byth K, Cheung NW: Serum 25hydroxyvitamin $D$ and glycated haemoglobin levels in women with gestational diabetes mellitus. Med J Aust 2011, 194(7):334-337.

101. Rudnicki PM, Molsted-Pedersen L: Effect of 1,25-dihydroxycholecalciferol on glucose metabolism in gestational diabetes mellitus. Diabetologia 1997, 40(1):40-44.

102. Merewood A, Mehta SD, Chen TC, Bauchner H, Holick MF: Association between vitamin $\mathrm{D}$ deficiency and primary cesarean section. J Clin Endocrinol Metab 2009, 94(3):940-945.

103. Brunvand L, Shah SS, Bergstrom S, Haug E: Vitamin D deficiency in pregnancy is not associated with obstructed labor. A study among Pakistani women in Karachi. Acta Obstet Gynecol Scand 1998, 77(3):303-306.

104. Allsworth JE, Peipert JF: Prevalence of bacterial vaginosis: 2001-2004 National Health and Nutrition Examination Survey data. Obstet Gynecol 2007, 109(1):114-120.

105. Hillier SL: Diagnostic microbiology of bacterial vaginosis. Am J Obstet Gynecol 1993, 169(2 Pt 2):455-459.

106. Lamont RF: Antibiotics for the prevention of preterm birth. N Engl J Med 2000, 342(8):581-583.

107. Bodnar LM, Krohn MA, Simhan HN: Maternal vitamin D deficiency is associated with bacterial vaginosis in the first trimester of pregnancy. $J$ Nutr 2009, 139(6):1157-1161.

108. Hensel KJ, Randis TM, Gelber SE, Ratner AJ: Pregnancy-specific association of vitamin D deficiency and bacterial vaginosis. Am J Obstet Gynecol 2011, 204(1):41 e41-49.

109. Davis LM, Chang SC, Mancini J, Nathanson MS, Witter FR, O'Brien KO: Vitamin D insufficiency is prevalent among pregnant African American adolescents. J Pediatr Adolesc Gynecol 2010, 23(1):45-52.

110. Liu PT, Stenger S, Li H, Wenzel L, Tan BH, Krutzik SR, Ochoa MT, Schauber J, Wu K, Meinken C, Kamen DL, Wagner M, Bals R, Steinmeyer A, Zugel U, Gallo RL, Eisenberg D, Hewison M, Hollis BW, Adams JS, Bloom BR, Modlin RL: Toll-like receptor triggering of a vitamin D-mediated human antimicrobial response. Science 2006, 311(5768):1770-1773.
111. Nizet V, Ohtake T, Lauth X, Trowbridge J, Rudisill J, Dorschner RA, Pestonjamasp V, Piraino J, Huttner K, Gallo RL: Innate antimicrobial peptide protects the skin from invasive bacterial infection. Nature 2001, 414(6862):454-457.

112. Chesney RW: Vitamin D and The Magic Mountain: the anti-infectious role of the vitamin. J Pediatr 2010, 156(5):698-703.

113. Muller K, Diamant $M$, Bendtzen K: Inhibition of production and function of interleukin- 6 by 1,25-dihydroxyvitamin D3. Immunol Lett 1991, 28(2):115-120.

114. Helming L, Bose J, Ehrchen J, Schiebe S, Frahm T, Geffers R, ProbstKepper M, Balling R, Lengeling A: 1alpha,25-Dihydroxyvitamin D3 is a potent suppressor of interferon gamma-mediated macrophage activation. Blood 2005, 106(13):4351-4358.

115. Bouillon R, Carmeliet G, Verlinden L, van Etten E, Verstuyf A, Luderer HF, Lieben L, Mathieu C, Demay M: Vitamin D and human health: lessons from vitamin D receptor null mice. Endocr Rev 2008, 29(6):726-776.

116. Liu N, Kaplan AT, Low J, Nguyen L, Liu GY, Equils O, Hewison M: Vitamin D induces innate antibacterial responses in human trophoblasts via an intracrine pathway. Biol Reprod 2009, 80(3):398-406.

117. Delorme AC, Danan JL, Acker MG, Ripoche MA, Mathieu H: In rat uterus 17 beta-estradiol stimulates a calcium-binding protein similar to the duodenal vitamin D-dependent calcium-binding protein. Endocrinology 1983, 113(4):1340-1347.

118. Tribe RM: Regulation of human myometrial contractility during pregnancy and labour: are calcium homeostatic pathways important? Exp Physiol 2001, 86(2):247-254.

119. Morley R, Carlin JB, Pasco JA, Wark JD: Maternal 25-hydroxyvitamin D and parathyroid hormone concentrations and offspring birth size. J Clin Endocrinol Metab 2006, 91(3):906-912.

120. Baker AM, Haeri S, Camargo CA, Stuebe AM, Boggess KA: A Nested CaseControl Study of First-Trimester Maternal Vitamin D Status and Risk for Spontaneous Preterm Birth. Am J Perinatol 2010, 95(11):5105-5109.

121. Mehta S, Giovannucci E, Mugusi FM, Spiegelman D, Aboud S, Hertzmark E, Msamanga Gl, Hunter D, Fawzi WW: Vitamin D status of HIV-infected women and its association with HIV disease progression, anemia, and mortality. PLoS One 2010, 5(1):e8770.

122. Bodnar $L M$, Simhan $H N$ : The prevalence of preterm birth and season of conception. Paediatr Perinat Epidemiol 2008, 22(6):538-545.

123. Hollis BW, Wagner CL: Randomized controlled trials to determine the safety of vitamin D supplementation during pregnancy and lactation. Fourteenth Workshop on Vitamin D Brugge, Belgium; 2009, 134.

124. Brooke OG, Brown IR, Bone CD, Carter ND, Cleeve HJ, Maxwell JD, Robinson VP, Winder SM: Vitamin D supplements in pregnant Asian women: effects on calcium status and fetal growth. Br Med J 1980, 280(6216):751-754.

125. Mallet E, Gugi B, Brunelle P, Henocq A, Basuyau JP, Lemeur H: Vitamin D supplementation in pregnancy: a controlled trial of two methods. Obstet Gynecol 1986, 68(3):300-304.

126. Yu CK, Sykes $L$, Sethi M, Teoh TG, Robinson S: Vitamin D deficiency and supplementation during pregnancy. Clin Endocrinol (Oxf) 2009, 70(5):685-690.

127. Marya RK, Rathee S, Lata V, Mudgil S: Effects of vitamin D supplementation in pregnancy. Gynecol Obstet Invest 1981, 12(3):155-161.

128. Akcakus M, Koklu E, Budak N, Kula M, Kurtoglu S, Koklu S: The relationship between birthweight, 25-hydroxyvitamin $\mathrm{D}$ concentrations and bone mineral status in neonates. Ann Trop Paediatr 2006, 26(4):267-275.

129. Prentice A, Jarjou LM, Goldberg GR, Bennett J, Cole TJ, Schoenmakers I: Maternal plasma 25-hydroxyvitamin D concentration and birthweight, growth and bone mineral accretion of Gambian infants. Acta Paediatr 2009, 98(8):1360-1362.

130. Leffelaar ER, Vrijkotte TG, van Eijsden M: Maternal early pregnancy vitamin $D$ status in relation to fetal and neonatal growth: results of the multiethnic Amsterdam Born Children and their Development cohort. $\mathrm{Br} J$ Nutr 2010, 104(1):108-117.

131. Scholl TO, Chen X: Vitamin D intake during pregnancy: association with maternal characteristics and infant birth weight. Early Hum Dev 2009, 85(4):231-234.

132. Gale CR, Robinson SM, Harvey NC, Javaid MK, Jiang B, Martyn CN, Godfrey KM, Cooper C: Maternal vitamin D status during pregnancy and child outcomes. Eur J Clin Nutr 2008, 62(1):68-77. 
133. Bowyer L, Catling-Paull C, Diamond T, Homer C, Davis G, Craig ME: Vitamin D, PTH and calcium levels in pregnant women and their neonates. Clin Endocrinol (Oxf) 2009, 70(3):372-377.

134. Morley R, Carlin JB, Pasco JA, Wark JD, Ponsonby AL: Maternal 25hydroxyvitamin $D$ concentration and offspring birth size: effect modification by infant VDR genotype. Eur J Clin Nutr 2009, 63(6):802-804

135. Bodnar LM, Catov JM, Zmuda JM, Cooper ME, Parrott MS, Roberts JM, Marazita ML, Simhan HN: Maternal serum 25-hydroxyvitamin D concentrations are associated with small-for-gestational age births in white women. J Nutr 2010, 140(5):999-1006

136. Namgung R, Tsang RC, Lee C, Han DG, Ho ML, Sierra RI: Low total body bone mineral content and high bone resorption in Korean winter-born versus summer-born newborn infants. J Pediatr 1998, 132(3 Pt 1):421-425.

137. Javaid MK, Crozier SR, Harvey NC, Gale CR, Dennison EM, Boucher BJ, Arden NK, Godfrey KM, Cooper C: Maternal vitamin D status during pregnancy and childhood bone mass at age 9 years: a longitudinal study. Lancet 2006, 367(9504):36-43.

138. Mahon P, Harvey N, Crozier S, Inskip H, Robinson S, Arden N, Swaminathan R, Cooper C, Godfrey K: Low maternal vitamin D status and fetal bone development: cohort study. J Bone Miner Res 2010, 25(1):14-19.

139. Viljakainen HT, Saarnio E, Hytinantti T, Miettinen M, Surcel H, Makitie O, Andersson S, Laitinen K, Lamberg-Allardt C: Maternal vitamin D status determines bone variables in the newborn. J Clin Endocrinol Metab 2010, 95(4):1749-1757

140. Brannon PM, Picciano MF: Vitamin d in pregnancy and lactation in humans. Annu Rev Nutr 2011, 31:89-115.

141. Dror DK, Allen LH: Vitamin D inadequacy in pregnancy: biology, outcomes, and interventions. Nutr Rev 2010, 68(8):465-477.

142. Haggerty LL: Maternal supplementation for prevention and treatment of vitamin D deficiency in exclusively breastfed infants. Breastfeed Med 2011, 6(3):137-144

143. Mulligan ML, Felton SK, Riek AE, Bernal-Mizrachi C: Implications of vitamin D deficiency in pregnancy and lactation. Am J Obstet Gynecol 2010, 202(5):429 e421-429.

144. Taylor SN, Wagner CL, Hollis BW: Vitamin D supplementation during lactation to support infant and mother. J Am Coll Nutr 2008, 27(6):690-701.

145. Kho AT, Bhattacharya S, Tantisira KG, Carey VJ, Gaedigk R, Leeder JS, Kohane IS, Weiss ST, Mariani TJ: Transcriptomic analysis of human lung development. Am J Respir Crit Care Med 2010, 181(1):54-63.

146. Barker DJ, Eriksson JG, Forsen T, Osmond C: Fetal origins of adult disease: strength of effects and biological basis. Int J Epidemiol 2002, 31(6):1235-1239.

147. Camargo CA, Rifas-Shiman SL, Litonjua AA, Rich-Edwards JW, Weiss ST, Gold DR, Kleinman K, Gillman MW: Maternal intake of vitamin D during pregnancy and risk of recurrent wheeze in children at $3 \mathrm{y}$ of age. Am J Clin Nutr 2007, 85(3):788-795.

148. Devereux G, Litonjua AA, Turner SW, Craig LC, McNeill G, Martindale S, Helms PJ, Seaton A, Weiss ST: Maternal vitamin D intake during pregnancy and early childhood wheezing. Am J Clin Nutr 2007, 85(3):853-859.

149. Erkkola M, Kaila M, Nwaru Bl, Kronberg-Kippila C, Ahonen S, Nevalainen J, Veijola R, Pekkanen J, Ilonen J, Simell O, Knip M, Virtanen SM: Maternal vitamin $D$ intake during pregnancy is inversely associated with asthma and allergic rhinitis in 5-year-old children. Clin Exp Allergy 2009, 39(6):875-882.

150. Davies G, Welham J, Chant D, Torrey EF, McGrath J: A systematic review and meta-analysis of Northern Hemisphere season of birth studies in schizophrenia. Schizophr Bull 2003, 29(3):587-593.

151. Altschuler EL: Low maternal vitamin D and schizophrenia in offspring. Lancet 2001, 358(9291):1464.

152. Mirzaei F, Michels KB, Munger K, O'Reilly E, Chitnis T, Forman MR, Giovannucci $E$, Rosner B, Ascherio A: Gestational vitamin D and the risk of multiple sclerosis in offspring. Ann Neurol 2011, 70(1):30-40.

153. Hypponen E, Laara E, Reunanen A, Jarvelin MR, Virtanen SM: Intake of vitamin D and risk of type 1 diabetes: a birth-cohort study. Lancet 2001 358(9292):1500-1503

154. Zipitis CS, Akobeng AK: Vitamin D supplementation in early childhood and risk of type 1 diabetes: a systematic review and meta-analysis. Arch Dis Child 2008, 93(6):512-517.
155. Stene LC, Ulriksen J, Magnus P, Joner G: Use of cod liver oil during pregnancy associated with lower risk of Type I diabetes in the offspring. Diabetologia 2000, 43(9):1093-1098.

156. Harris SS: Vitamin D in type 1 diabetes prevention. J Nutr 2005, 135(2):323-325.

157. Krishnaveni GV, Veena SR, Winder NR, Hill JC, Noonan K, Boucher BJ, Karat SC, Fall CH: Maternal vitamin D status during pregnancy and body composition and cardiovascular risk markers in Indian children: the Mysore Parthenon Study. Am J Clin Nutr 2011, 93(3):628-635.

158. Fronczak CM, Baron AE, Chase HP, Ross C, Brady HL, Hoffman M, Eisenbarth GS, Rewers M, Norris JM: In utero dietary exposures and risk of islet autoimmunity in children. Diabetes Care 2003, 26(12):3237-3242.

159. Papandreou D, Malindretos P, Karabouta Z, Rousso I: Possible Health Implications and Low Vitamin D Status during Childhood and Adolescence: An Updated Mini Review. Int J Endocrinol 2010, 2010:472173.

160. Lapillonne A: Vitamin D deficiency during pregnancy may impair maternal and fetal outcomes. Med Hypotheses 2010, 74(1):71-75.

161. Lanham-New SA, Buttriss JL, Miles LM, Ashwell M, Berry JL, Boucher BJ, Cashman KD, Cooper C, Darling AL, Francis RM, Fraser WD, de Groot CP, Hypponen E, Kiely M, Lamberg-Allardt C, Macdonald HM, Martineau AR, Masud T, Mavroeidi A, Nowson C, Prentice A, Stone EM, Reddy S, Vieth R, Williams CM: Proceedings of the rank forum on vitamin d. Br J Nutr 2011, 105(1):144-156.

162. Ross AC, Manson JE, Abrams SA, Aloia JF, Brannon PM, Clinton SK, DurazoArvizu RA, Gallagher JC, Gallo RL, Jones G, Kovacs CS, Mayne ST, Rosen CJ, Shapses SA: The 2011 report on dietary reference intakes for calcium and vitamin D from the Institute of Medicine: what clinicians need to know. J Clin Endocrinol Metab 2011, 96(1):53-58.

163. Bischoff-Ferrari H: Vitamin D: what is an adequate vitamin D level and how much supplementation is necessary? Best Pract Res Clin Rheumatol 2009, 23(6):789-795.

164. Bischoff-Ferrari HA, Shao A, Dawson-Hughes B, Hathcock J, Giovannucci E, Willett WC: Benefit-risk assessment of vitamin D supplementation. Osteoporos Int 2010, 21(7):1121-1132.

165. Hollis BW, Wagner CL: Assessment of dietary vitamin D requirements during pregnancy and lactation. Am J Clin Nutr 2004, 79(5):717-726.

166. Hollis BW, Johnson D, Hulsey TC, Ebeling M, Wagner CL: Vitamin D supplementation during pregnancy: Double blind, randomized clinical trial of safety and effectiveness. J Bone Miner Res 2011.

doi:10.1186/1477-7827-9-146

Cite this article as: Grundmann and von Versen-Höynck: Vitamin D roles in women's reproductive health? Reproductive Biology and Endocrinology 2011 9:146

\section{Submit your next manuscript to BioMed Central and take full advantage of:}

- Convenient online submission

- Thorough peer review

- No space constraints or color figure charges

- Immediate publication on acceptance

- Inclusion in PubMed, CAS, Scopus and Google Scholar

- Research which is freely available for redistribution

Submit your manuscript at www.biomedcentral.com/submit
C Biomed Central 